\section{Flaming fronts of fire}

\section{J. A. J. Gowlett}

Burning Bush: A Fire History of Australia. By Stephen J. Pyne. Holt: 1991. Pp.520. £19.95, \$27.95.

FIRE strikes deep chords in the human psyche. Terror of wildfire is balanced by love of the essential hearth - the heart of figurative speech in all language. In one of many Australian aboriginal fire myths, giant kangaroos attack humans until they are driven off by fire, which the people then keep safely in the bole of a eucalyptus tree. Fire history encompasses much that is comparably odd or romantic, so it becomes a bold undertaking to weld together an account embracing both natural phenomena and human influences on a continental scale. Stephen J. Pyne had the enthusiasm to do this for the Americas, and now has turned his attention to Australia.

Throughout Burning Bush: A Fire History of Australia, Pyne deals in colourfully fiery language. After the break-up of Gondwana, Australia followed a separate destiny, drifting through the oceans on its own evolutionary path. Fire had touched other continents, but here, Pyne explains, it was something much more deep-rooted: fire branded Australia, "pervasive, persistent, singular". A constant and essential theme of the book is that those species which have shaped Australian fire have been, in turn, shaped by it. First among all these is the eucalyptus, the gum, in all its variety of more than 600 species. Next perhaps is the acacia; then humans - the aborigines, the early white settlers, and finally the farmers, foresters and government commissions.

Such a theme demands almost an epic, and in spite of a disclaimer, Pyne provides it. At times he writes a veritable fire poetry. As in Homer, key phrases become familiar, favourite stories recur; and also, there are subsidiary plots, followed one by one to their logical conclusions before the main theme is rejoined. The volume is divided into books; fire sweeps, spouts and glows on every page. Here there is a potted fire history of Britain, because of the British colonization; there, of California because of its similar Mediterranean environment; of the outlying islands because they were not shaped by human occupation.

This concentrated stream of fire is aimed not at one audience, but in the author's own desire two, those of America and Australia. I would go further, and say that the book is suitably pitched for both general and academic audiences anywhere in the Englishspeaking world, provided only that they have the stamina for such a tour de force. The vigorous metaphorical style is not, however, a cover for a work lacking in content. The author covers his ground in remarkable detail, backing up his text with many pages of bibliographic notes. He starts by working systematically through the natural environment, emphasizing the variety of its fire potential. In heath, for example, more than 90 per cent of vegetation is available for burning, but in Acacia brigalow less than 0.1 per cent. Then there is the coming of the aborigines, the 'firestick farmers' who burned regularly in the course of everyday life, flushing game, stimulating new growth and undoubtedly altering the fire regimes dramatically. Descriptions of aboriginal fire practices and beliefs are treated well. After early European settlement come the later phases or organized fire control and legislation.

For those concerned with the past, the most interesting question of all is likely to be the interaction of climatic change, vegetation change, the coming of the aborigines, and the disappearance of the megafauna. The sclero-

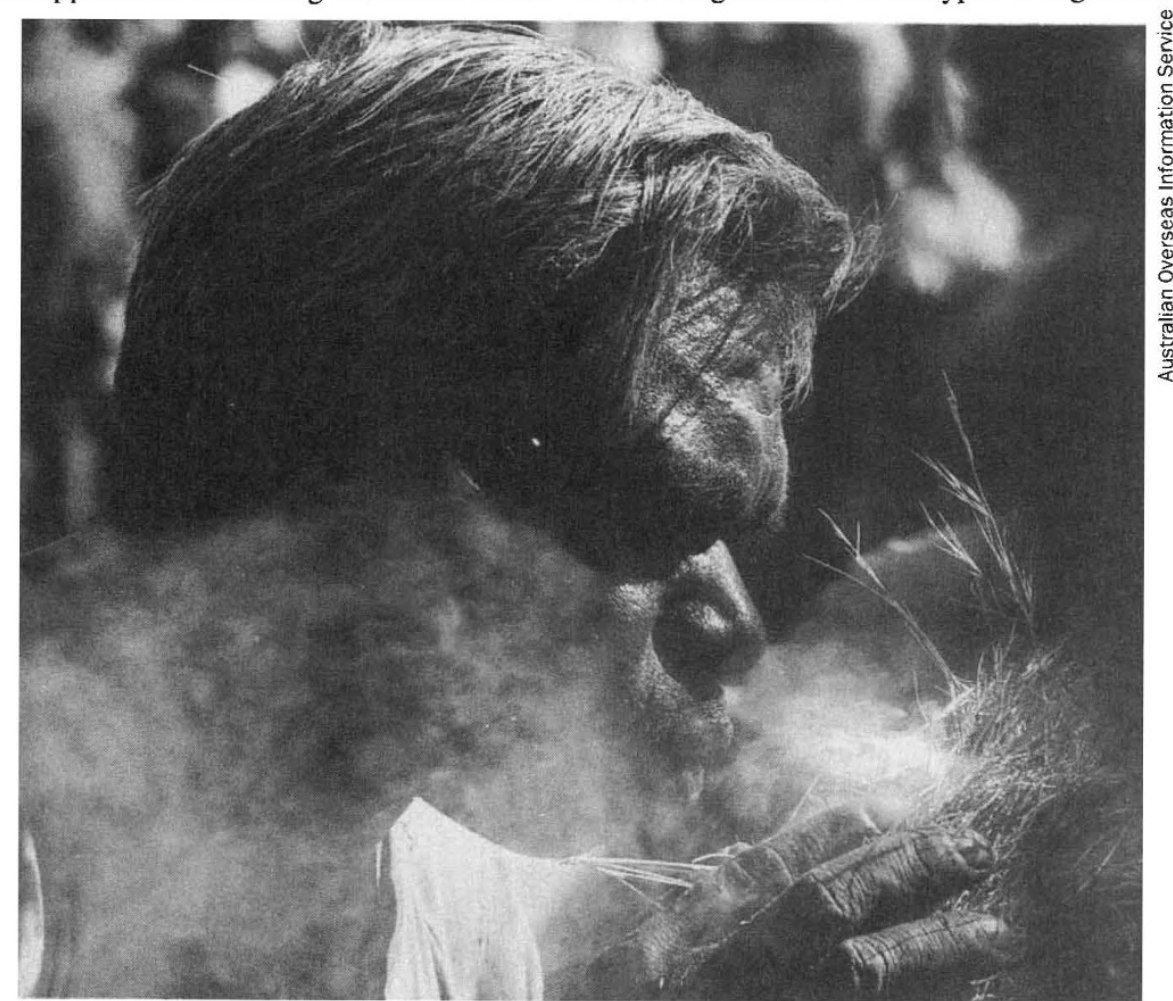

Fanning the flame - an aborigine kindles dry grass in the ancient way.

morphic eucalyptus has expanded greatly during the last glaciation, much reducing the cover of rainforest. The first human occupation goes back over 40,000 years; some of the megafauna survived much after then. Was climate the main agent of change, or did the more regular and systematic burning of the 'firestick farmers', coupled with their hunting, contribute to the disappearance of the giant kangaroos and wombats?

Questions of the present are not much easier to answer: the problems of fire are not past history. During the last major fires on Ash Wednesday 1983 fire tornadoes were recorded, one ranging up to 375 metres high; 180 fires started in the southeast on the one day, ten raging out of control, burning more than 350,000 hectares and claiming over 70 lives. These follow the past parade of Red Tuesday, Black Thursdays, Fridays, and Sundays. No management strategy is feasible that will expunge fire entirely. Pyne draws a contrast with the approaches taken in North America, which concentrate more on suppression. Time and again Australians have reverted to the notion that regular controlled burning is necessary to prevent inordinate amounts of fuel building up. Hence the dictum of the forester Harry Luke, that fire control means fuel control.

A book such as this could easily give the impression that fire is everything, the dominant infuence of all; but this is not quite what the author says, in spite of his devotion to his subject. If occasionally it looks as if we are getting just one side of a story, Pyne always comes back with a critical analysis. Fire is not paramount in Australia. There are areas where rainforest has reintroduced itself since the last glaciation. Some types of vegetation have evolved so that fire cannot flourish within them. Victoria, which has suffered more than half the total economic damage from bushfires, represents less than three per cent of Australia's landmass. Modern human influence has made more of fire, made its escape from controlled fire to bushfire most costly. Objectively the true significance of fire is difficult to measure. For Professor Pyne, and for the aborigines in their 'dreamtime', its importance can hardly be exaggerated. In the face of a bushfire, who would venture to say that they are wrong? $\square$

J. A. J. Gowlett is in the Department of Archaeology, University of Liverpool, The Hartley Building, P.O. Box 147, Liverpool L69 3BX, UK. 